\title{
The influence of feeding purple wheat with higher content of anthocyanins on antioxidant status and selected enzyme activity of animals
}

\author{
Eva Mrkvicová ${ }^{1}$, Leoš Pavlata $^{1}$, Filip Karásek ${ }^{1}$, Ondřej Št’astník ${ }^{1}$, Eva Doležalová ${ }^{1}$ \\ Václav Trojan ${ }^{2}$, Tomáš Vyhnánek ${ }^{2}$, Luděk Hřivna ${ }^{3}$, Veronika Holeksová1, Jan Mareš ${ }^{4}$, \\ Tomáš Brabec ${ }^{4}$, Pavel Horký1, Branislav Ruttkay-Nedeckýs ${ }^{5}$, Vojtěch Adam ${ }^{5}$, René Kizek ${ }^{5}$ \\ Mendel University in Brno, Faculty of AgriSciences, ${ }^{1}$ Department of Animal Nutrition and Forage Production, \\ ${ }^{2}$ Department of Plant Biology, ${ }^{3}$ Department of Food Technology, ${ }^{4}$ Department of Zoology, Fisheries, \\ Hydrobiology and Apiculture, ${ }^{5}$ Department of Chemistry and Biochemistry, Brno, Czech Republic
}

Received October 13, 2015

Accepted October 26, 2016

\begin{abstract}
The influence of anthocyanins on antioxidant activity and liver function was measured in three different animal species (rats, chickens and fish). Purple Konini wheat with the total anthocyanin content (TAC) of $41.70 \mathrm{mg} / \mathrm{kg}$ was fed to the experimental groups of animals (rats $\mathrm{n}=32$; chickens $n=32$; fish $n=20$ ). The same numbers of animals (control groups) were fed common wheat with TAC of $24.95 \mathrm{mg} / \mathrm{kg}$. At the end of the experiment, the animals were killed and blood and liver tissues were taken for biochemical analyses. The liver enzyme activities were measured in blood. Antioxidant activity in the liver tissue was measured using the DPPH (2,2-diphenyl1-picrylhydrazyl test), FR (Free Radicals method), FRAP (Ferric Reducing Antioxidant Power method), and ABTS (2,2'-azino-bis(3-ethylbenzothiazoline-6-sulphonic acid) test. Significantly higher values $(P<0.05)$ measured by the DPPH and FR methods were determined in the liver from rats fed Konini wheat. The chickens fed Konini wheat showed significantly different values using DPPH, FR and ABTS methods. No significant differences were found in hepatopancreases of fish. Animals fed Konini wheat showed a tendency to lower liver enzyme activities in general, but a significant difference was found only in gamma-glutamyl transferase activity in the chicken's blood. Our results suggest that feeding a higher content of anthocyanins can improve the antioxidant activity and function of the liver tissue.
\end{abstract}

Rats, chickens, fish, free radicals, radical scavenging activity

Besides the contents of nutrients and toxic substances in rations, researchers lately increasingly focus on the biologically active substances with protective and preventive effects against the degenerative diseases and other health problems that may lead to the shortening of life (Ficco et al. 2014; Kaur et al. 2014). In recent years, much attention has been paid to researching a number of substances with antioxidant action, which include vitamins, microelements, and many other compounds naturally occurring in plants and producing positive effects both in human and animal nutrition (Abdel-Aal and Hucl 2003; Englmaierová et al. 2011; Suchý et al. 2014; Sun et al. 2014). Health benefits have been partly attributed to the unique phytochemicals present in the whole grain (Liu 2007). Flavonoids possess antioxidant properties against reactive oxygen species.Antiallergic, anti-inflammatory, and analgesic effects were also demonstrated, including the ability to affect nutrient transfer at the capillary level (Opletal and Skřivanová 2010). In crop species, the edible organs show large variations in colour. In the wheat grain, which is a staple food for humans and grain feed for animals, the colour is mainly due to natural classes of pigment: carotenoids and anthocyanins. Anthocyanins accumulate in the aleurone or pericarp of wheat and provide the blue, purple and red colours of the grain (Ficco et al. 2014). Anthocyanins could be the major compounds distinguishing purple wheat from other coloured wheats for their high antioxidant activity (Liu et al. 2010). It is well known that herbal anthocyanins are functioning as antioxidants and, in addition, they have anti-

Address for correspondence:

Eva Mrkvicová

Department of Animal Nutrition and Forage Production

Faculty of AgriSciences, Mendel University in Brno

Phone: +420545133174

Zemědělská 1, 61300 Brno, Czech Republic 
bacterial and anti-carcinogenic effects (Liu et al. 2010; Varga et al. 2013). Correlation between the content of anthocyanins and antioxidant activity has been established. The highest correlation was found between the total reducing power and total anthocyanins $(\mathrm{r}=0.97)$ (Mitic et al. 2014). Anthocyanins also have therapeutic effects against tissue inflammation, capillary fragility, cardiovascular diseases, cancer, hyperglycaemia, and oxidative liver damage in humans (Mazza 2000; Kähkönen and Heinonen 2003; Broncel et al. 2007; Giampieri et al. 2012; Hassellund et al. 2012). The influence of anthocyanins in food for human and animal consumption needs to be monitored. When Kirakosyan et al. (2015) fed rats with tart cherry, the highest concentration of anthocyanins was found in the liver. Therefore, increased antioxidant activity in this organ is expected.

The aim of this study was to investigate the effect of feeding purple Konini wheat with a higher content of total anthocyanins on the antioxidant status and liver tissue function in different animal species.

\section{Materials and Methods}

Wheat and diets used in the experiment

Purple Konini wheat with a higher total anthocyanin content (TAC) of $41.70 \mathrm{mg} / \mathrm{kg}$ was used for the experiment. For control groups, common Bohemia wheat with TAC of $24.95 \mathrm{mg} / \mathrm{kg}$ was used. The total anthocyanin content was determined spectrophotometrically, recalculated and expressed in the content of cyanidin-3-glucosid. The method described by Lee et al. (2005) was used for determination of TAC in wheat.

The animals were fed wheat only. The nutrient content in the experimental diets is described in Table 1. Control wheat and Konini wheat were the only feed fed to the animals so as to eliminate possible influences of other antioxidants. The diets were fed to the rats, chickens and fishes. The content of crude protein in diets for chickens and rats was increased in the control feed using wheat gluten to be identical as in Konini wheat.

Table 1. Content of nutrients in wheat diets (data are converted to $100 \%$ of dry matter).

\begin{tabular}{|c|c|c|c|c|c|}
\hline & Crude ash & Crude protein & Crude fat & Crude fibre & Brutto energy \\
\hline & \multicolumn{4}{|c|}{$\%$ of dry matter } & $\mathrm{MJ} / \mathrm{kg}$ \\
\hline Control group & 1.79 & 16.98 & 1.61 & 2.39 & 17.56 \\
\hline Konini group & 2.08 & 16.15 & 1.83 & 2.56 & 17.60 \\
\hline
\end{tabular}

\section{Experimental animals}

The experiment was carried out in three different animal species, chickens, rats, and fish representing three different models of animals (birds, mammals, fish) with a high percentage of cereals in the diet. The animal procedures were reviewed and approved by the Animal Care Committee of Mendel University in Brno. Animals were divided into two groups, control and experimental. Control groups were fed control wheat with a lower TAC (Bohemia) and experimental groups were fed Konini wheat with a higher TAC.

Trial with rats:

Selected male laboratory rats of the Wistar Albino strain $(n=64)$ at the age of 9 weeks were divided into two groups. Rats were marked by shaving off specific areas and kept in plastic boxes with 8 rats per box. The initial average live weight of rats was $259.06 \pm 20.05 \mathrm{~g}$. The values of room temperature $\left(20-23^{\circ} \mathrm{C}\right)$ and humidity $(50-60 \%)$ were controlled. Lighting system was $16 \mathrm{~h}$ light and $8 \mathrm{~h}$ dark. The experimental group $(\mathrm{n}=32)$ was fed milled wheat in pelleted form $(100 \%$ purple Konini wheat). The control group $(n=32)$ was fed milled control wheat in pelleted form (100\% common wheat with gluten) ad libitum. The dry matter of experimental diets was $89.1 \%$. Body weight gains were followed at two-day intervals and the feed consumption was followed daily. The experiment continued for 23 days.

At the age of 85 days the rats were anaesthetised using Isoflurane and bled. Blood samples were obtained by cardiac puncture using a test tube with heparin. The liver tissues were collected and frozen at $-72{ }^{\circ} \mathrm{C}$.

Trial with chickens:

Sixty four chickens of the hybrid combination COBB 500 with a wing sign with number were divided into two groups at the age of 39 days with the average live weight of $2,472.7 \pm 180.48 \mathrm{~g}$. They were bred in balance cages. Room temperature and humidity were controlled (mean values $21{ }^{\circ} \mathrm{C}$ and $60 \%$, respectively). Lighting system was $16 \mathrm{~h}$ light and $8 \mathrm{~h}$ dark. The experimental group $(\mathrm{n}=32)$ was fed a coarse meal of purple Konini wheat $(100 \%$ wheat in the diet). The control group $(\mathrm{n}=32)$ was fed a coarse meal of common wheat with gluten. The diets for 
chickens were identical with the diets for rats but not pelleted (the content of nutrients in the diets is described in Table 1). Chickens were fed ad libitum and the feed consumption was controlled daily. The experiment continued for 15 days.

Up to day 39 of age the chickens obtained diets with $78 \%$ of wheat (the control group receiving common wheat and the experimental group receiving purple Konini wheat), $13.1 \%$ of soy-bean meal, $0.6 \%$ of wheat starch, $0.7 \%$ of monocalcium phosphate, $0.3 \%$ of milled limestone, $4 \%$ rapeseed oil, and $3.3 \%$ of a premix (concentrate of microelements). The nutrient content in the diets was in accordance with the recommended nutrient content in poultry diets and nutritive values of feeds for poultry (Zelenka et al. 2007).

Blood samples from the brachial vein were taken into heparinised tubes at the age of 54 days. Chickens were slaughtered by decapitation, eviscerated, and samples of liver were taken for laboratory analyses. The samples were frozen $\left(-72{ }^{\circ} \mathrm{C}\right)$.

Trial with fish:

The fingerlings of common carp (Cyprinus carpio L.) of the Amurský lysec line from Rybníkárství Pohořelice Inc., Czech Republic, were used for the feeding test. Fish with the average live weight of $56.75 \pm 13.36 \mathrm{~g}$ were placed in 200 litre glass tanks, 50 animals per tank. Rearing tanks were connected to a recirculation system with mechanical and biological phases of water treatment. Hydrochemical properties of water were regularly recorded during the feeding test. The oxygen content, temperature and $\mathrm{pH}$ (Multimeter Hach Lange HQ 40d, Germany) were measured in each aquarium always before the morning and evening feedings. The content of ammonium ions, chlorides, and nitrites (spectrophotometer WTW PhotoLab 6600 UV VIS, Germany) using standard sets (WTW, Germany) according to the method of Horáková (2007) were measured every day before morning feeding.

Tanks were sorted into two groups, each with two replicates: the experimental group with crushed purple wheat, and the control group with crushed standard wheat. The feeding ration for wheat was $1.5 \%$ of fish stock weight, and for natural food (frozen Chironomids larvae) it was $0.2 \%$ of fish stock weight to all variants. Table grinder was used for grinding the wheat. In order to prevent scrub, the grinding process was set to the maximum graininess for the mechanical disrupting of each grain. The feeding regime was set at three feedings per day during the light period, at 8:00 h, 13:00 h, and 18:00 h. Control and Konini wheat were divided into two sub-parts and administered to fish at 8:00 $\mathrm{h}$ and 13:00 h. Natural food was administered at 18:00 h. The light regime was set at 13 hours light and 11 hours dark. Fish were weighed in groups once a week for modification of the feeding ration. The feeding test took 34 days. Blood samples of experimental carp were taken by heparinized syringe immediately after pulling the fish out of tanks using the cardio-puncture method (Svobodová et al. 1986) at the end of experiment. From each fish $0.5-1.5 \mathrm{ml}$ of blood was taken. Particular samples were transferred into $2 \mathrm{ml}$ Eppendorf tubes, sealed and cooled to $8{ }^{\circ} \mathrm{C}$ (Eppendorf ThermoStat plus). Subsequently, the samples were placed in a freezing box and stored at $-72{ }^{\circ} \mathrm{C}$ (Arctiko Ul TF 80 ). Fish were stunned by a blow to the head and killed by decapitation. The samples of hepatopancreas was taken after the killing, frozen at $-72{ }^{\circ} \mathrm{C}$ and stored for another analyses.

\section{Laboratory methods}

Selected enzymatic activities in blood: gamma-glutamyl transferase (GGT), aspartate aminotransferase (AST), alanine aminotransferase (ALT), and alkaline phosphatase (ALP) were measured by the Mindray BS 400 biochemical analyser using commercial test kits (Greiner, Germany).

Preparation of liver samples for antioxidant activity measuring:

Frozen liver samples were mixed and homogenized with the addition of liquid nitrogen by homogenizer (Heidolph DIAX 900, Germany). The sample of $0.2 \mathrm{~g}$ of liver tissue was taken to the micro test tube Eppendorf (capacity $1.5 \mathrm{ml})$ and $1 \mathrm{ml}$ of phosphate buffer $\left(\mathrm{pH} 7\left(\mathrm{NaH}_{2} \mathrm{PO}_{4}-9.078 \mathrm{~g} / 1+\mathrm{Na}_{2} \mathrm{HPO}_{4} 11.876 \mathrm{~g} / \mathrm{l}\right)\right.$ was added. The content was homogenized for 2 min by ultrasound needle (Bandelin SONOPULS, Germany). Everything was done in cooling conditions on dry ice. After cell disintegration, the test tubes were put into the shaker (VortexGenie 2, Germany) for $15 \mathrm{~min}$ for homogenisation of liquid suspension. After that, homogenized samples were put in the Eppendorf Centrifuge $5417 \mathrm{R}$ (Eppendorf, Germany) and centrifuged for $30 \mathrm{~min}$ at $4{ }^{\circ} \mathrm{C}$ and $3,000 \mathrm{~g}$. After centrifugation, the supernatant was taken and analysed.

Spectrophotometric measurements of antioxidant activity and total proteins were carried out using the BS-400 automated chemical analyser (Mindray, Shenzhencity, China). Determination of antioxidant activity by the 2,2-diphenyl-1-picrylhydrazyl (DPPH) test, Ferric Reducing Antioxidant Power (FRAP) method, Free Radicals (FR) method and ABTS (2,2'-azino-bis(3-ethylbenzothiazoline-6-sulphonic acid) test were made according to the methods of Sochor et al. (2010). The DPPH is expressed in \% of inhibition; the FR, FRAP, and ABTS values are recalculated and expressed in the gallic acid equivalent (GAE) in $\mathrm{mg} / \mathrm{g}$ of protein.

Total protein was determined by the Total Protein kit (Greiner Diagnostic GmbH, Germany), using the Biuret method which is a test used for detecting the presence of peptide bonds. In the presence of peptides, a copper ion forms a violet-coloured complex in alkaline solution. A $150 \mu 1$ volume of Biuret reagent (100 mM potassium sodium tartrate, $100 \mathrm{mM}$ sodium hydroxide, $15 \mathrm{mM}$ potassium iodide and $6 \mathrm{mM}$ copper ${ }^{(I)}$ sulphate) is pipetted into a plastic cuvette with subsequent addition of $3 \mu 1$ of sample. Absorbance is measured at $\lambda=546 \mathrm{~nm}$ after 10 min of incubation. The resulting value is calculated from the absorbance value of the pure Biuret reagent and from the absorbance value after $10 \mathrm{~min}$ of incubation with the sample. Calibration curve was prepared by measuring the serial dilution of protein standard $(40 \mathrm{~g} / \mathrm{l})$ from the kit. 
Statistical analysis

Data were processed using Microsoft Excel ${ }^{\circledR}$ (USA) and Statistica CZ Version 10.0 (Czech Republic). Results are expressed as mean \pm standard deviation (S.D.) unless noted otherwise $\left(\right.$ Excel $\left.^{\circledR}\right)$. Significance of the differences between experimental groups was determined using Statistica CZ (one-way Anova, Sheffe's test).

\section{Results and Discussion}

Rats

The duration of the experiment with rats was 23 days. During this period, body weight gains and feed consumptions did not differ significantly between the groups of rats (feed consumption was $15.52 \mathrm{~kg}$ in the control group, and $14.52 \mathrm{~kg}$ in the Konini group; mean body weight at the end of experiment was $303.26 \pm 26.20 \mathrm{~g} /$ animal in the control group, and $291.62 \pm 26.32 \mathrm{~g} /$ animal in the Konini group).

\section{Chickens}

During the part of the experiment when the chickens were fed only wheat with different contents of anthocyanins (15 days), the feed consumption was $57.86 \mathrm{~kg}$ in the control group and $60.40 \mathrm{~kg}$ in the Konini group. The mean live weight of individual chickens was $2,602.67 \pm 328.76 \mathrm{~g}$ in the control group, and 2,315.50 $\pm 371.73 \mathrm{~g}$ in the Konini group at the end of the experiment (54 days of age). Differences between the groups were not significant.

\section{Fish}

Feed consumption during the feeding test (34 days) was $2.83 \mathrm{~kg}$ of control wheat, $2.79 \mathrm{~kg}$ of Konini wheat; and $428.3 \mathrm{~g}$ of Chironomids larvae in the control group, and $421.3 \mathrm{~g}$ in the Konini group. The mean live weight of carp was $58.81 \pm 10.98 \mathrm{~g}$ in the control group and $57.91 \pm 11.57 \mathrm{~g}$ in the Konini group at the end of experiment. Differences between the groups were not significant.

It is evident from these results that the feeding of purple Konini wheat with a higher content of anthocyanins had no negative or positive effect on feed consumption and body weight gain of animals. The overall low daily body weight gains in the experimental period must be put into context with the fact that the study investigated the effect of anthocyanins. Furthermore, the animals were fed a mono-diet (purple Konini wheat or common wheat), which did not cover the optimum nutrient requirements of individual animal species and ages.

The influence of purple Konini wheat with a higher content of anthocyanins on the liver enzyme activities and antioxidant status of liver tissues of chickens, rats, and fish are described in the Table 2.

Significantly higher values $(P<0.05)$ of antioxidant status measured by the DPPH and FR methods were determined in the liver of rats fed purple Konini wheat. The chickens fed Konini wheat showed significantly higher values $(P<0.05)$ as measured by DPPH and ABTS methods but lower values as measured by FR method. No significant differences $(P>0.05)$ were found in hepatopancreas of fish. Animals fed Konini wheat had generally lower liver enzyme activities, but a significant difference was found only in the gammaglutamyl transferase activity in the blood of chickens $(P<0.05)$. These results suggest that the feeding of Konini wheat with a higher content of anthocyanins can improve the antioxidant activity and function of the liver tissues as suggested by selected enzyme activity.

Considering the fact that the purple Konini cultivar of wheat has a high content of anthocyanins which in most scientific articles are presented as antioxidants (Liu et al. 2010), we expected an increase in the antioxidant status of animals. Our results are in 


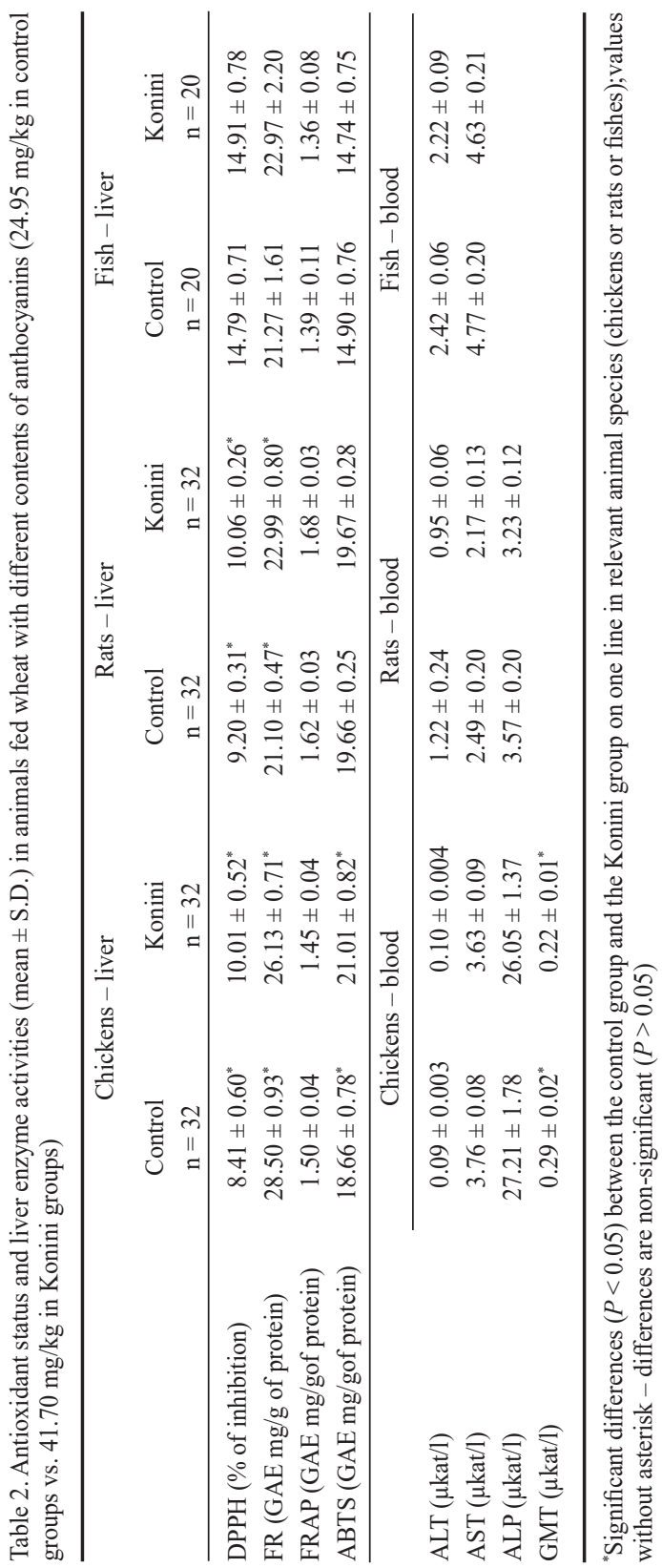

accordance with these findings because most measured indicators of antioxidant activity were higher in the Konini groups. Coloured varieties of crops have a higher antioxidant potential thanks to anthocyanins. The antioxidant activity of these crops is mainly expressed in higher levels of antioxidants determined by ABTS and DPPH methods (Flores et al. 2015).

Kirakosyan et al. (2015) observed a higher content of anthocyanins in rat livers experimenting with tart cherry. From these results could be assumed an increase in antioxidant activity in this organ. Antioxidant statuses determined by the DPPH, FR, FRAP or ABTS methods were used as well for measurement of antioxidant activity in liver, semen and in erythrocytes (Alia et al. 2003; Suzen et al. 2006; Horky et al. 2012; Horky et al. 2013). In the experiment of Ghafoor and Al Juhaimi (2014) the positive effect of anthocyanins on health status of the liver was described depending on the dose of anthocyanins administered in several different raw materials (raspberry, blackberry, plum and cereals).

Based on our results we can conclude that a similar effect was also observed in our experiment. According to some authors, increased antioxidant activity also improved the health status of organs and tissues, hence the whole organism (Wang et al. 2014). Significantly higher antioxidant activity was observed in our experimental chickens and rats fed a higher content of anthocyanins. Conversely, in our experiment with fish, significant differences were not observed in any of the measured indices. It is therefore possible that the metabolism of fish could not utilize the forms of anthocyanins used. Further investigation in this area (especially assessing the plasma antioxidant potential) could be very useful.

\section{Acknowledgement}

The research was financially supported by the project by TP IGA FA MENDELU in Brno 4/2015. 


\section{References}

Abdel-Aal ESM, Hucl P 2003: Composition and stability of anthocyanins in blue-grained wheat. J Agr Food Chem 51: 2174-2180

Alia M, Horcajo U, Bravo L, Goya L 2003: Effect of grape antioxidant dietary fiber on the total antioxidant capacity and the activity of liver antioxidant enzymes in rats. Nutr Res 23: 1251-1267

Broncel M, Koziróg-Kolacińska M, Andryskowski G, Duchnovicz P, Koter-Michalak M, Owczarczyk A, Chojnowska-Jezierska J 2007: Effect of anthocyanins from Aronia melanocarpa on blood pressure, concentration of endothelin-1 and lipids in patients with metabolit syndrome. Polski Merkuriusz Lekarski 23: 116-119

Englmaierová M, Bubancová I, Vít T, Skřivan M 2011: The effect of lycopene and vitamin E on growth performance, quality and oxidative stability of chicken leg meat. Czech J Anim Sci 56: 536-543

Ficco DBM, Mastrangelo AM, Trono D, Borrelli GM, De Vita P, Fares C, Beleggia R, Platini C, Papa R 2014: The colours of durum wheat: a review. Crop Pasture Sci 65: 1-15

Flores G, Wu SB, Negrin A, Kennelly EJ 2015: Chemical composition and antioxidant activity of seven cultivars of guava (Psidium guajava) fruits. Food Chem 170: 327-335

Ghafoor K, Al Juhaimi FY 2014: Effects of anthocyanins as nutraceuticals. Agro Food Ind Hi-Tec 25: 9-13

Giampieri F, Alvarez-Suarez JM, Tulipani S, Gonzales-Paramas AM, Santos-Buelga C, Bompadre S, Quiles JL, Mezzettib B, Battino M 2012: Photoprotective potential of strawberry (Fragaria $\times$ ananassa) extract against UV-A irradiation damage on human fibroblasts. J Agr Food Chem 60: 2322-2327

Hassellund S, Flaa A, Kjeldsen S, Seljeflot I, Karlsen A, Erlund I, Rostrup M 2012: Effects of anthocyanins on cardiovascular risk factors and inflammation in pre-hypertensive men: a double-blind randomized placebocontrolled crossover study. J Hum Hypertens 27: 100-106

Horáková M (Ed.) 2007: Water Analytics. VŠCHT Prague, $2^{\text {nd }}$ edn, 335 p.

Horky P, Jancikova P, Sochor J, Hynek D, Chavis GJ, Ruttkay-Nedecky B, Cernei N, Zitka O, Zeman L, Adam V, Kizek R 2012: Effect of organic and inorganic form of selenium on antioxidant status of breeding boars ejaculate revealed by electrochemistry. Int J Electrochem Sci 7: 9643-9657

Horky P, Ruttkay-Nedecky B, Kremplova M, Krystofova O, Kensova R, Hynek D, Babula P, Zitka O, Zeman L, Adam V, Kizek R 2013: Effect of different doses of organically bound selenium on antioxidant status and levels of metal ions in postpartum sows. Int J Electrochem Sci 8: 6162-6179

Kähkönen MP, Heinonen M 2003: Antioxidant activity of anthocyanins and their aglycons. J Agr Food Chem 51: $628-633$

Kaur KD, Jha A, Sabikhi L, Singh AK 2014: Significance of coarse cereals in health and nutrition: a review. J Food Sci Technol 51: 1429-1441

Kirakosyan A, Seymour EM, Wolforth J, McNish R, Kaufman PB, Bolling SF 2015: Tissue bioavailability of anthocyanins from whole tart cherry in healthy rats. Food Chem 171: 26-31

Lee J, Durst RW, Wrolstad RE 2005: Determination of total monomeric anthocyanin pigment content of fruit juices, beverages, natural colorants, and wines by the $\mathrm{pH}$ differential method: Collaborative study. J AOAC Int 88: 1269-1278

Liu RH 2007: Whole grain phytochemicals and health. J Cereal Sci 46: 207-219

Liu Q, Qiu Y, Beta T 2010: Comparison of antioxidant activities of different colored wheat grains and analysis of phenolic compounds. J Agr Food Chem 58: 9235-9241

Mitic V, Stankov Jovanovic V, Dimitrijevic M, Cvetkovic J, Simonovic S, Nikolic Mandic S 2014: Chemometric analysis of antioxidant activity and anthocyanin content of selected wild and cultivated small fruit from Serbia. Fruits 69: 413-422

Mazza G 2000: Health aspects of natural colours. In: Lauro GJ, Francis FJ (Eds): Natural Food Colourants: Science and Technology. CRC Press, New York, pp. 289-314

Opletal L, Skřivanová V 2010: Natural substances and their biological activity (in Czech). Karolinum, Praha, $653 \mathrm{p}$.

Sochor J, Ryvolova M, Krystofova O, Salas P, Hubalek J, Adam V, Trnkova L, Havel L, Beklova M, Zehnalek J, Provaznik I, Kizek R 2010: Fully automated spectrometric protocols for determination of antioxidant activity: advantages and disadvantages. Molecules 15: 8618-8640

Suchý P, Straková E, Herzig I 2014: Selenium in poultry nutrition: a review. Czech J Anim Sci 59: 495-503

Sun B, Ma J, Zhang J, Su L, Xie Q, Bi Y 2014: Lycopene regulates production performance, antioxidant capacity, and biochemical parameters in breeding hens. Czech J Anim Sci 59: 471-479

Suzen S, Gurkok G, Coban T 2006: Novel N-acyl dehydroalanine derivatives as antioxidants: Studies on rat liver lipid peroxidation levels and DPPH free radical scavenging aktivity. J Enzym Inhib Med Chem 21: 179-185

Svobodová Z, Pravda D, Paláčková J 1986: Uniform methods of haematological analyses of fish (in Czech). VÚRH Vodňany, $36 \mathrm{p}$.

Varga M, Bánhidy L, Czeus L, Matuz J 2013: The anthocyanin content of blue and purple coloured wheat cultivars and their hybrid generations. Cereal Res Commun 41: 284-292

Wang WC, Li JL, Wang Z, Gao H, Su L, Xie J, Chen XH, Liang H, Wang CB, Han YT 2014: Oral hepatoprotective ability evaluation of purple sweet potato anthocyanins on acute and chronic chemical liver injuries. Cell Biochem Biophys 69: 539-548

Zelenka J, Heger J, Zeman L 2007: Recommended nutrient content in poultry diets and nutritive value of feeds for poultry (in Czech). MZLU v Brně, Brno, 78 p. 